KS. KAZIMIERZ DULLAK

Wydział Teologiczny

Uniwersytetu Szczecińskiego

ORCID: 0000-0002-9202-0433

\title{
PRZYGOTOWANIE DO MAŁŻEŃSTWA MIESZANEGO W ŚWIETLE DEKRETU OGÓLNEGO EPISKOPATU POLSKI Z 8.10.2019 ROKU
}

Treść: Wstęp. - 1. Ogólne zasady. - 2. Troska Kościoła o świętość związku małżeńskiego. - 3. Dokumenty. - 4. Obrzędy zawarcia małżeństw. - Zakończenie.

\section{Wstęp}

Przez wiele lat trwały prace, w ramach Komisji Prawnej Konferencji Episkopatu Polski, nad dokumentem mającym na celu uaktualnienie uregulowań dotyczących bezpośredniego przygotowania do małżeństwa. Dotychczas obowiązująca Instrukcja z 1986 r. ${ }^{1}$ w bardzo dużej części zdezaktualizowała się wskutek nowych regulacji prawnych jak również zmieniających się uwarunkowań społecznych w Polsce. Autorzy nowego dokumentu w swoim opracowaniu położyli duży nacisk

\footnotetext{
${ }^{1}$ Konferencja Episkopatu Polski, Instrukcja Konferencji Episkopatu Polski o przygotowaniu do zawarcia małżenstwa w Kościele katolickim, Akta Konferencji Episkopatu Polski 1 (1998), s. 85-137. Dokument ten był przyjęty przez zebranie plenarne KEP 5.09.1986 r., Stolica Apostolska zatwierdziła jej treść dekretem z 17.01.1987 r. zaś Przewodniczący Konferencji Episkopatu Polski promulgował ją $13.12 .1989 \mathrm{r}$.
} 
na jeden $z$ elementów przygotowania do małżeństwa ${ }^{2}$, a mianowicie na przeprowadzenie rozmów kanoniczno-duszpasterskich $z$ narzeczonymi przed zawarciem kanonicznego małżeństwa ${ }^{3}$. Tak też został zatytułowany tenże dekret ogólny KEP wydany 8.10.2019 r., który następnie 4.11.2019 r. uzyskał recognitio Kongregacji ds. Biskupów, natomiast 26.11.2019 r. został promulgowany przez episkopat, a wszedł w życie 1.06.2020 r. Pozostałe elementy przygotowania, a zwłaszcza etapu bezpośredniego, mają swoje odzwierciedlenie w innych aktach prawnych o zasięgu ogólnokościelnym ${ }^{4}$, jak i partykularnym - na gruncie polskim 5 .

Warto na tym etapie uwypuklić cele, jakim służy wydany dekret ogólny, opisując przebieg spotkania kancelaryjnego. Episkopat już we wprowadzeniu wskazuje iż „celem egzaminu przedślubnego narzeczonych jest rozeznanie ich sytuacji prawnej i upewnienie się

\footnotetext{
${ }^{2}$ Konferencja Episkopatu Polski, Dyrektorium duszpasterstwa rodzin (1.05.2003), Warszawa 2003, nr 29; Konferencja Episkopatu Polski, Służyć prawdzie o małżństwie i rodzinie (1.09.2009), Warszawa 2009, nr 98.

${ }^{3}$ Konferencja Episkopatu Polski, Dekret ogólny o przeprowadzeniu rozmów kanoniczno-duszpasterskich z narzeczonymi przed zawarciem małżeństwa kanonicznego (20.01.2020), w: https://episkopat.pl/aktakep312019 [dostęp 5.09.2020] - dalej: DO.

${ }^{4}$ Jan PaweŁ II, Adhortacja Familiaris consortio (22.11.1981), w: Adhortacje Ojca Świętego Jana Pawła II, t. 1, Kraków 2006; Franciszek, Adhortacja Amoris Laetitia (19.03.2016), Kraków 2016; PAPIEsKA RADA Ds. Rodziny, Przygotowanie do sakramentu małżeństwa (13.05.1996 r.), w: Troska o dobro małżeństwa i rodziny. Dokumenty Papieskiej Rady ds. Rodziny, t. 1, (red. M. Brzeziński), Lublin 2010, S. 175-205.

${ }^{5}$ Konferencja Episkopatu Polski, Dyrektorium (1.05.2003), nr 18-36. Ponadto warto wspomnieć inne dokumenty KEP: instrukcję dla duszpasterzy dotyczącą małżeństw konkordatowych z 22.10.1998 r., instrukcję w sprawie duszpasterstwa małżeństw o różnej przynależności kościelnej z 11.03.1997 r., stanowisko biskupów w sprawie małżeństwa katolickiego zawieranego poza miejscem świętym z 16.04.2016 r., wytyczne pastoralne do adhortacji Amoris Laetitia z 8.06.2018 r., Pro memoria Rady Prawnej dotyczące relacji duszpasterskich Kościoła łacińskiego z katolikami Kościołów wschodnich z 4.10.2018 r., dekret ogólny w sprawie ochrony osób fizycznych w związku z przetwarzaniem danych osobowych w Kościele katolickim z 13.03.2018 r.
} 
o należytym przygotowaniu do zawarcia małżeństwa"'. Chodzi tu o wykluczenie istnienia przeszkód zrywających lub zaradzenia im poprzez dyspensę, w ramach możliwości prawnych. Ponadto należy zbadać czy nupturienci mają właściwą intencję zawarcia małżeństwa oraz czy nie są objęci innymi zakazami, a także czy świadek kwalifikowany posiada odpowiednie uprawienia i czy zostały dopełnione wszelkie czynności związane ze skutkami cywilnymi małżeństwa kanonicznego.

Wskazany w tytule wątek kierunkujący na małżeństwa mieszane uwzględnia sytuacje, w których jednym z nupturientów obok wyznawcy rzymskokatolickiego jest osoba, która nie jest w pełnej łączności z Kościołem katolickim lub nie jest chrześcijaninem. Tak więc chodzi o małżeństwa mieszane (kan. $1124 \mathrm{KPK})^{7}$ lub zawierane z przeszkodą różnej religii od której została udzielona dyspensa ordynariusza miejsca (kan. $1086 \$ 1 \mathrm{KPK})^{8}$. Jak pisze Z. Janczewski, termin małżeństwo mieszane używamy w podwójnym znaczeniu: ścisłym i szerokim. W pierwszej odmianie obok katolika jest ochrzczony, nie należący do Kościoła katolickiego, a w drugiej, w grę wchodzi małżeństwo katolika z niekatolikiem ochrzczonym lub nieochrzczonym ${ }^{9}$.

Niniejsze opracowanie ma na celu wyłuszczenie i przybliżenie tych treści dekretu ogólnego które dotyczą bezpośredniego przygotowania do małżeństwa osób, tworzących małżeństwa mieszane w szerokim znaczeniu ${ }^{10}$. Zostanie zwrócona uwaga, najpierw na

${ }^{6} \mathrm{DO}$ wprowadzenie.

${ }^{7}$ Codex Iuris Canonici auctoritate Ioannis Pauli PP II promulgatus, AAS 75 (1983) II; tłumaczenie polskie: Kodeks Prawa Kanonicznego, przekład polski zatwierdzony przez KEP, Pallottinum 1984.

${ }^{8}$ M. GóźDź, Przymierze. Fundamentalne założenia prawodawstwa małżeńskiego Kościoła rzymskokatolickiego i Kościołów ewangelickich, Katowice 2019, s. 148-150; M. Tuszyńska, Małżeństwa mieszane w prawie kanonicznym, Kortowski Przegląd Prawniczy 4 (2016), s. 156-157.

${ }^{9}$ Z. Janczewski, Prawodawstwo Konferencji Episkopatu Polski i prymasa kard. S. Wyszyńskiego $w$ zakresie sakramentów w służbie wspólnoty: święceń i małżństwa, Prawo Kanoniczne 42(1999) nr 1-2, s. 125.

${ }^{10}$ Małżeństwa mieszane w szerokim znaczeniu, zgodnie $\mathrm{z}$ omawianym dokumentem, należy rozumieć w ten sposób, że wchodzą w grę następujące konstelacje 
ogólne zasady według których należy się kierować podczas spotkań z narzeczonymi. Następnie zostanie odzwierciedlona troska Kościoła o dobro sakramentu albo dobro małżeństwa kanonicznego pobłogosławionego w Kościele. W dalszej części, uwaga zostanie skupiona na dokumentach niezbędnych lub pomocnych w doprowadzeniu do zawarcia małżeństwa na forum kościelnym. Ostatnia część przybliży regulacje związane $z$ obrzędowością małżeńską czyli unormowania związane z liturgią podczas której dochodzi do zawarcia małżeństwa w Kościele katolickim.

\section{Ogólne zasady}

Zawieranie małżeństw na forum Kościoła katolickiego daje uprawnienie kompetentnej władzy kościelnej do określenia przesłanek, których w dalszym etapie należy przestrzegać i według których należy postępować. Zasady te kierowane są zarówno do osób odpowiedzialnych za należyte przygotowanie narzeczonych do zawarcia małżeństwa, jak również do samych narzeczonych. Stolica Apostolska zaleca, by przygotowanie do małżeństwa traktować indywidualnie, wykorzystując jednocześnie każdą okazję, by pomóc im zrozumieć sens tego, co dokonuje się poprzez zawarcie małżeństwa ${ }^{11}$.

Punktem wyjścia jest zgłoszenie się narzeczonych do kancelarii parafialnej w celu wymiany podstawowych informacji i omówienia tych zagadnień, które tego wymagają ${ }^{12}$. Podczas pierwszego spotkania

małżeńskie: 1/ katolik z ochrzczonym niekatolikiem (DO 70); 2/ katolik z osobą nieochrzczoną (DO 73); 3/ „katolików, który odstąpił od Kościoła, ochrzczonych katolików deklarujących się jako niewierzacy oraz tych katolików, którzy uporczywie nie praktykuja wiary (kan. $1071 \$ 2 \mathrm{KPK}$ ). W sprawach dotyczących zawarcia małżeństwa wszyscy oni są zrównani z niekatolikami” (DO 74).

${ }^{11}$ PAPIeska Rada ds. Rodziny, Przygotowanie (13.05.1996), nr 51.

${ }^{12}$ Omawiany dokument choć w dużej mierze koncentruje się na aspekcie kancelaryjnym, to jednak KEP w innym dokumencie eksponuje w procesie przygotowania do małżeństwa działanie duszpasterskie: „Trzeba, aby był to czas intensywnej ewangelizacji, prowadzącej do nawrócenia, czyli - w tym wypadku - odkrycia bądź pogłębienia Bożej wizji małżeństwa oraz odkrycia bądź ożywienia osobistej zażyłości z Bogiem”. Konferencja Episkopatu Polski, Służyć prawdzie (19.06.2009), nr 98. 
$\mathrm{w}$ biurze $\mathrm{z}$ narzeczonymi duszpasterz udzieli informacji o wymogach przygotowania bezpośredniego do małżeństwa oraz o tym, jakie winni zgromadzić dokumenty (DO 1). Drugie spotkanie podczas którego duszpasterz wypełnia protokół rozmów kanoniczno-duszpasterskich przed zawarciem małżeństwa, powinno rozpocząć się zachętą do wspólnej modlitwy kapłana z narzeczonymi. Propozycja ta będzie zależała od przebiegu rozmowy wcześniej przeprowadzonej w której narzeczeni podzielą się tym, jakie znaczenie ma łaska Boża w ich życiu, powiedzą o własnym podejściu do odpowiedzialności za chrześcijańskie małżeństwo, jak również o czynnym i świadomym udziale w obrzędzie zaślubin ${ }^{13}$ (DO 2). Z powyższego wynika, iż episkopat przyzwala na to, by zaniechać propozycji wspólnej modlitwy. Przyczyny są dwie: zauważalny opór ze strony narzeczonych lub wyraźne negatywne nastawienie do takiego aktu religijnego.

$\mathrm{W}$ dalszym etapie, przed zadawaniem indywidualnie każdemu $\mathrm{z}$ narzeczonych pytań przewidzianych $\mathrm{w}$ protokole ${ }^{14}$, duszpasterz powinien odebrać od nich przysięgę mówienia prawdy, zgodnie z rotą zamieszczoną $\mathrm{w}$ formularzu, czyli zobowiązuje narzeczonych do prawdomówności. Już w samym dokumencie podkreślono, iż „przysięga ta ma na celu podkreślenie doniosłości badania kanonicznego nupturientów w kontekście ważności małżeństwa, zaakcentowanie odpowiedzialności i wzmocnienie wiarygodności narzeczonych" (DO 4). Ten nowy wymóg należy traktować z należytą powagą, jako akt religijny. Nie mniej jednak, mając na uwadze osoby o różnej przynależności religijnej jak również osoby niereligijne, należy liczyć się z odmową złożenia przysięgi ${ }^{15}$. Opór ze strony narzeczonych, czy to

\footnotetext{
${ }^{13}$ JAN PAWEe II, Familiaris consortio (22.11.1981), nr 67.

${ }^{14}$ Benedictus XVI, Ad sodales Tribunalis Romanae Rotae, AAS 103 (2011), s. 108 -113; A. BARTCZAK, Przygotowanie do zawarcia małżństwa w świetle przemówienia Benedykta XVI do Roty Rzymskiej z 2011 r., Łódzkie Studia Teologiczne 20 (2011), s. 29-30.

${ }^{15}$ Dla odzwierciedlenia złożoności problemu, warto za Motu proprio Matrimonia mixta papieża Pawła VI przytoczyć pojęcie „osoby niegodne”, które mogą być jedną z osób chcących zawrzeć małżeństwo w Kościele katolickim. Chodzi o tych, którzy formalnie wystąpili z Kościoła katolickiego, albo są znani jako czynnie zwalczający
} 
dotyczący religijnego charakteru przysięgi, czy też samego meritum jej treści, należy jednoznacznie zinterpretować i odnotować ten fakt w protokole ${ }^{16}$. Nie należy jednak odstępować od dalszego przygotowania do małżeństwa. Podczas rozmowy z nupturientami, od duszpasterza wymaga się zachowania nie tylko dyskrecji, ale i kultury oraz uszanowania ich godności (DO 6). Episkopat podkreśla, że te i wszystkie inne zasady należy stosować zarówno do nupturientów przygotowujących się do małżeństwa mieszanego w wąskim znaczeniu jak również małżeństwa katolików z nieochrzczonymi (DO 71 i 73).

W treści rozmów, przeprowadzanych przez duszpasterza $z$ narzeczonymi, należy z powagą i poczuciem odpowiedzialności podjąć zagadnienia dotyczące trudności z jakimi mogą się zetknąć na gruncie zróżnicowania wyznaniowego lub religijnego ${ }^{17}$. Chodzi o praktykowanie wiary, chrzest dzieci i ich religijne wychowanie, o zróżnicowanie w moralnej ocenie niektórych spraw. Dlatego „należy wskazać nupturientom te zagrożenia, zapytać, jak we wspólnym życiu zamierzają rozwiązywać konflikty związane z życiem religijnym oraz wskazać drogi takich rozwiązań" (DO 75). Nie może zabraknąć ze strony duszpasterza, podczas omawianego spotkania, tematów wyjaśniających otwarcie zasady nauki katolickiej dotyczące jedności, nierozerwalności małżeństwa oraz jego celów ${ }^{18}$. „Pierwszym zadaniem duszpasterza jest dopomóc w odkryciu wiary, jej umocnieniu i doprowadzeniu do

Kościół, albo stali się publicznymi grzesznikami lub pozostają w karach kościelnych za apostazję i uporczywie w nich trwają. Zob. PAweŁ VI, Motu proprio Matrimonia mixta (31.03.1970 r.), Prawo Kanoniczne 14(1971) nr 3-4, s. 239-249.

${ }^{16}$ „Odmowa złożenia przysięgi z zasady nie powinna być przyczyną odstąpienia od przygotowania do małżeństwa, ale fakt ten powinien być okazją do zwrócenia uwagi narzeczonym na ewentualne trudności, z jakimi mogą się zmierzyć w przyszłym małżeństwie" (DO 4).

${ }^{17}$ P. JaskóŁa, Ut sit unum. Wprowadzenie do ekumenizmu, Opole 2018, s. 107-108.

${ }^{18}$ PAPIESKa RAda DS. Jedności Chrześcijan, Dyrektorium w sprawie realizacji zasad i norm dotyczących ekumenizmu z 25 marca 1993 r., nr 149-150, w: Ut unum. Dokumenty Kościoła katolickiego na temat ekumenizmu 1982-1998, (red. S.C. Napiórkowski, K. Leśniewski, J. Leśniewska), Lublin 2000, s. 77-78. 
dojrzałości. Należy także do niego ukazanie, jak dla dobra rodziny i jej przyszłości potrzebna jest małżeńska zgoda, więź i harmonia" (DO 76). Treści te, choć stanowiące kluczowe podwaliny nauczania Kościoła, należy przekazywać zachowując delikatność, a zarazem kategoryczność (o czym w dalszej części opracowania) wobec odmiennych poglądów reprezentowanych przez nupturientów.

\section{Troska Kościoła o świętość związku małżeńskiego}

Szacunek do człowieka o rozmaitych przekonaniach i poglądach, nie może stanowić dla Kościoła pretekstu odstępowania od troski o depozyt wiary. Dlatego małżeństwo mieszane - w wąskim znaczeniu (dwoje ochrzczonych o różnej przynależności wyznaniowej) z założenia jest związkiem zabronionym bez wyraźnego zezwolenia ordynariusza miejsca (kan. $1125 \mathrm{KPK}$ ). U podstaw tego zakazu jest przede wszystkim potencjalna trudność w istotnych sferach życia małżonków, których dzielą różnice wyznaniowe. Autorzy dokumentu selektywnie wymieniają niektóre $\mathrm{z}$ nich: rozbieżności w pojmowaniu małżeństwa, zagrożenie wierności wobec własnego Kościoła, niebezpieczeństwo indyferentyzmu religijnego, utrudnienie praktyki wiary, czy problemy w religijnym wychowaniu dzieci. Wyliczenie niektórych spośród całej palety potencjalnych trudności małżeńskich, ma na celu uświadomienie zakochanym w sobie, z jakimi trudnościami prawdopodobnie zderzą się we wspólnocie małżeńskiej (DO 70). To uświadomienie nie idzie w kierunku zniechęcenia do małżeństwa, ale podprowadza do wartości, których wspólnie doświadczą. Obok wspomnianych zagrożeń, Kościół przytacza ważną zasadę wynikającą z prawa naturalnego: „Małżeństwo mogą zawrzeć wszyscy, którym prawo tego nie zabrania” (kan. 1058 KPK). Dlatego Kościół udziela zezwolenia na zawarcie tego rodzaju małżeństwa tym, którzy o to proszą. Musi jednak istnieć słuszna i rozumna przyczyna oraz wykluczone zostaje realne niebezpieczeństwo utraty wiary przez katolickiego małżonka, a także zagwarantowane są jego prawa w odniesieniu do praktykowania wiary i wychowania potomstwa.

Episkopat Polski w omawianym dokumencie nalega, by podczas przygotowań do zawarcia małżeństwa mieszanego kłaść nacisk na 
pozytywne aspekty, co dla nupturientów jest wspólne w życiu łaski, cnót teologalnych czy udzielania się darów Ducha Świętego. Każde z małżonków wierząc według własnych przekonań i wprowadzając je w praktykę, powinno dążyć do tego, co może prowadzić do jedności i harmonii. Elementem spajającym - zdaniem episkopatu - jest troska narzeczonych o coraz lepsze wzajemne poznawanie przekonań religijnych drugiej strony oraz nauki i praktyki jej Kościoła lub Wspólnoty eklezjalnej (DO 72) ${ }^{19}$. Niemniej jednak, nie można przemilczeć istotnego faktu, a mianowicie tego, iż zawierane małżeństwo niesie dla obojga identyczne wymagania co do nierozerwalności i wierności ${ }^{20}$. Nie wchodzą w grę zróżnicowane zapatrywania strony niekatolickiej lub niewierzącej na przymioty małżeńskie, to znaczy że zawarte małżeństwo będzie dla obojga jedno i nierozerwalne $e^{21}$. Przeciwne poglądy kandydatów do małżeństwa, każą duchownemu katolickiemu podjąć stanowczą decyzję o przerwaniu dalszych procedur zmierzających do zawarcia małżeństwa w Kościele katolickim, gdyż skutkowałoby ono jego nieważnością (DO 77). Można tu zauważyć proporcjonalność tonu wybrzmiewającego $\mathrm{w}$ dokumencie, w relacji do potencjalnych

\footnotetext{
${ }^{19}$ Papieska Rada ds. Jedności Chrześcijan, Dyrektorium z 25.03.1993 r., nr 145; Konferencja Episkopatu Polski, Dyrektorium (1.05.2003), nr 36.

${ }^{20}$ Złożoność wspomnianej problematyki można zaprezentować na przykładzie związków zawartych pomiędzy katolikiem a prawosławnym. Zob. U. NowickA, Stwierdzenie stanu wolnego wiernych prawosławnych na forum Kościoła katolickiego. Warszawa 2012, s. 100-109.

${ }^{21}$ „Zgłaszających się nupturientów o różnej przynależności kościelnej trzeba pouczyć o jedności i nierozerwalności ważnie zawartego związku małżeńskiego (winna to uznać strona niekatolicka nawet, gdyby w jej wyznaniu był dopuszczalny rozwód), jak również o tym, że jedność wyznania w rodzinie jest ze wszech miar pożądana, gdyż jest fundamentem pokoju i pełnej wspólnoty, podczas gdy z różnicy wyznania wynikają poważne trudności, zwłaszcza dla religijnego wychowania dzieci. Pouczenia te jednak mają być wolne od niewłaściwego prozelityzmu i nie mogą naruszać zasady wolności sumienia w podejmowaniu decyzji przez nupturientów" (nr IV,3), Instrukcja Episkopatu Polski w sprawie duszpasterstwa małżeństw o różnej przynależności kościelnej (14.03.1987), w: Dokumenty duszpastersko-liturgiczne Episkopatu Polski (1966-1993), (red. Cz. Krakowiak, L. Adamowicz), Lublin 1994.
} 
skutków wynikających z braku jednomyślności w odniesieniu do przymiotów małżeńskich. Ze strony władz Kościoła pojawia się jednoznaczność w tej materii, brak akceptacji nauki Kościoła po stronie niekatolika, zamyka możliwość doprowadzenia kandydatów do małżeństwa.

Dla podkreślenia komplementarności nauczania chrześcijańskiego biskupi zachęcają duszpasterzy, wiedząc że jest to zadanie nie łatwe, by w miarę możliwości, nawiązali kontakt z szafarzem z innego Kościoła lub Wspólnoty eklezjalnej (DO 71). Do podobnego spotkania zachęcani są również narzeczeni. Celem tego spotkania nupturientów z szafarzem strony niekatolickiej jest weryfikacja zdolności prawnej nupturienta niekatolickiego $\mathrm{w}$ świetle jego własnego systemu prawa małżeńskiego (DO 80) ${ }^{22}$. Oba wymienione tu zalecenia mają na celu pielęgnowanie wartości ekumenicznych. Każde bowiem spotkanie pozwala lepiej wzajemnie się poznać i do siebie się zbliżać. Takie spotkania mogą pomóc w przezwyciężeniu stereotypów oraz uprzedzeń. Należy, jak podkreślał Jan Paweł II, zawierzyć się Bożej opatrzności, a wówczas dojdziemy do lepszego wzajemnego poznania się i zbliżenia ${ }^{23}$.

Troska KEP o dobro małżeństwa przejawia się w jeszcze jednej dyspozycji zawartej w omawianym dokumencie. Chodzi o decyzje strony niekatolickiej wyrażającą gotowość, w okresie przygotowania do małżeństwa, przyjęcia chrztu lub przystąpienia do pełnej wspólnoty z Kościołem katolickim. Taki krok musi być w pełni wolny, pozbawiony najmniejszych nacisków lub innych wpływów, zaś ze strony duchownego dokładnie zweryfikowany z uwzględnieniem przyczyny i stopnia dojrzałości tejże decyzji. Po pozytywnej weryfikacji należy podjąć działania w kierunku odbycia katechumenatu zgodnie z kan.

\footnotetext{
${ }^{22}$ L. Adamowicz, Prace Konferencji Episkopatu Polski nad nowa regulacją przygotowania do zawarcia małżeństwa kanonicznego (cz. II), Biuletyn Stowarzyszenia Kanonistów Polskich 32 (2019), s. 12.

${ }^{23}$ Jan PaweŁ II, Przemówienie podczas spotkania ekumenicznego w parku Thiugvellir (3.06.1989): Jedność chrześcijan stanie się darem Boga w Jego czasie łaski, w: Tegoż, Dzieła zebrane, t. XI, Kraków 2009, s. 553-556.
} 
$865 \$ 1$ KPK. Należy też zweryfikować czas przygotowania do chrztu z planowanym terminem zawarcia małżeństwa i ostatecznie ustalić etapy działania. Najprawdopodobniej sakrament chrztu będzie udzielony po zawarciu małżeństwa, tak by decyzja pełnego włączenia się do Kościoła katolickiego nie była niczym ponaglana (DO 81) ${ }^{24}$.

\section{Dokumenty}

Bardzo istotnym elementem w procesie kanonicznego badania narzeczonych jest gromadzenie niezbędnej dokumentacji. Tak jak w całym omawianym procesie chodzi o zbadanie stanu wolnego i predyspozycyjności nupturientów do zawarcia małżeństwa, tak również zgromadzenie dokumentów ma ten sam cel. Dlatego również stronę niekatolicką, jeśli jest ochrzczona, należy zobowiązać do przedłożenia świadectwa chrztu. Gdyby pojawiły się wątpliwości zarówno co do faktu chrztu, jak również co do ważności udzielonego sakramentu, należy konieczne zwrócić się do ordynariusza miejsca. O ile wątpliwości nie da się wyjaśnić, to celem tego zabiegu jest, „by obok zezwolenia na zawarcie małżeństwa mieszanego została udzielona ad cautelam dyspensa od przeszkody różnicy religii” (DO 78). Tego typu zabieg, mający na uwadze ważność małżeństwa, stanowi novum w dotychczasowej praktyce kanonicznej. Udzielenie dyspensy na okoliczność ewentualnego braku chrztu, czy to z racji na nieudzielenie go lub udzielenie w sposób nie uznawany przez Kościół katolicki jest wyrazem troski Episkopatu Polski o ważność związku małżeńskiego (DO 41).

Troska episkopatu o dobro małżeństwa polega również i na tym, by przeprowadzając formalności przedślubne uwzględnić te regulacje prawne, które wiążą wszystkich, bez względu na przynależność religijną czy nawet areligijność jednej ze stron. Chodzi o to, by w protokole badania kanonicznego narzeczonych pytać zarówno jedną jak i drugą stronę o istotne przymioty i cele małżeńskie, nie można pominąć tych kwestii w odniesieniu do niekatolików, nie można

\footnotetext{
${ }^{24}$ Instrukcja Episkopatu Polski w sprawie duszpasterstwa małżeństw o różnej przynależności kościelnej (14.03.1987), nr IV, 5.
} 
też nie zauważyć różnego, od katolickiego, podejścia do znaczenia przymiotów małżeńskich ${ }^{25}$. „Jest wymogiem prawa Bożego, obowiązującego również ochrzczonych niekatolików i osoby nieochrzczone, aby zawierając ważne małżeństwo mieli wolę wiernego i otwartego na potomstwo trwania w nim aż do śmierci" (DO 67). Dlatego podpisane przez stronę katolicką rękojmie są zapewnieniem świadomości przymiotów, a zwłaszcza celów małżeńskich, które podejmuje w sposób odpowiedzialny. Natomiast druga strona - niekatolicka, gdyby przyjąwszy do wiadomości zobowiązania katolika wyraźnie oświadczyłaby, że zrobi wszystko, by nie dopuścić do ich realizacji, ma być pouczona przez duszpasterza, „że małżeństwo, które zamierzają zawrzeć, ma być wspólnotą ich życia i miłości wobec Boga, a Kościół katolicki nie może akceptować sytuacji potencjalnie konfliktowej dla zawiązującego się ogniska rodzinnego, dotyczącej sfery najistotniejszych wartości” (DO 85). Gdyby te pouczenia nie przyniosły pozytywnego skutku, duszpasterz przedstawi sprawę ordynariuszowi miejsca. Gdyby ten „doszedł do przekonania, że wiara katolickiego nupturienta jest realnie, a nie tylko potencjalnie, narażona na niebezpieczeństwo, nie mógłby udzielić zezwolenia lub dyspensy" (DO 85).

Inna sytuacja dotyczy katolików obrządku wschodniego zawierających małżeństwo z katolikiem obrządku zachodniego. Należy mieć na uwadze prawo wschodnie, które jest ich specyfiką. I tak, kan. $809 \$ 1 \mathrm{KKKW}^{26}$ zabrania ważnie zawrzeć małżeństwo $\mathrm{z}$ powinowatym drugiego stopnia linii bocznej zaś kan. $811 \$ 1 \mathrm{KKKW}$ powtarza ograniczenie w wypadku pokrewieństwa duchowego. Należy w tych sytuacjach podjąć działania zmierzające do uzyskania dyspensy od hierarchy miejsca zamieszkania nupturienta obrządku wschodniego

${ }^{25}$ A. BArtczak, Przygotowanie do zawarcia małżeństwa, s. 28-29; M. Góźdź, Aktualność i znaczenie wymagań stawianych nupturientom o różnej przynależności wyznaniowej i religijnej w świetle kan. 1025 Kodeksu prawa kanonicznego (1983), w: Miłość i odpowiedzialność - wyznaczniki kanonicznego przygotowania do małżeństwa, red. A. Pastwa, M. Góźdź, Katowice 2013, s. 160-165.

${ }^{26}$ Codex Canonum Orientalium auctoritate Ioannis Pauli PP. II promulgatus. Typis Polyglottis Vaticanis 1990; tłumaczenie polskie: Kodeks Kanonów Kościołów Wschodnich promulgowany przez papieża Jana Pawła II, Lublin 2002. 
(DO 59). Ponadto należy pamiętać, że narzeczonych należących do obrządku wschodniego obowiązuje prawo wykluczające zawarcie małżeństwa pod jakimkolwiek warunkiem ${ }^{27}$.

W tym samym duchu adresaci dokumentu KEP muszą pamiętać o ważnej zasadzie: w zakresie kanonicznym nie można stosować narzędzi niekatolickich w dopuszczeniu do zawarcia kolejnego małżeństwa po rozwodzie. Tym samym nie można zgadzać się z dokumentami wydanymi przez niekatolickie organy władzy duchownej, które stwierdzają stan wolny kandydata do małżeństwa po otrzymaniu decyzji rozwodu cywilnego lub decyzji hierarchy prawosławnego o zezwoleniu na drugie lub trzecie małżeństwo. W takich sytuacjach episkopat jednoznacznie stwierdza, że stan wolny kandydata do małżeństwa mieszanego musi być stwierdzony przy zastosowaniu przepisów prawa kanonicznego (DO 79). Te z kolei nakazują, zachowanie szczególnej rozwagi przy sprawdzaniu stanu wolnego osób, nie należących do Kościoła katolickiego, a które zawarły związki małżeńskie według prawa swego wyznania lub religii, albo według formy cywilnej. Prawodawca wyraźnie suponuje, że należy domniemywać ważność i nierozerwalność takich związków. Nawet przedstawione dokumenty potwierdzające fakt, że małżeństwo takie uległo rozwiązaniu nie zmieniają stanu faktycznego. Bywa bowiem tak, w Kościołach i Wspólnotach eklezjalnych uznających zgodnie ze stosowanym u nich prawem i praktyką, że w określonych warunkach uznają rozwody i zezwalają na ponowne małżeństwa. Mając powyższe na uwadze, zawsze, gdy któreś z nupturientów zawarło wcześniej małżeństwo poza Kościołem katolickim, duszpasterz jest zobowiązany uprzedzić narzeczonych o konieczności przeprowadzenia dokładnej weryfikacji ich stanu wolnego. W kolejnym kroku, zwróci się o dokument zawierający zgodę ordynariusza miejsca na asystowanie przy takim małżeństwie. Zgoda może być wydana w oparciu o dokładny opis stanu sprawy i złożone dokumenty takie jak: prawomocny wyrok rozwodowy oraz załącznik (nr 1a) do protokołu z rozmów

\footnotetext{
${ }^{27}$ Kan. 826 KKKW jest skonstruowany w inny sposób niż kan. 1102 KPK a zwłaszcza $\$ 2$.
} 
kanoniczno-duszpasterskich z narzeczonymi (DO 40; 86). Ponadto, stan wolny niekatolika „zawsze musi być potwierdzony przysięgą zainteresowanego oraz dwóch świadków" (DO 42; por. 43). Dokonuje się to przez zaprzysiężone zeznania świadków znających nupturienta od osiągnięcia przezeń pełnoletniości oraz zaprzysiężonego zapewnienia o stanie wolnym samego zainteresowanego. Taki tok postępowania $\mathrm{w}$ dochodzeniu potwierdzenia stanu wolnego obowiązuje zarówno nieochrzczonych, ochrzczonych niekatolików oraz tych, którzy przyjęli chrzest po osiągnięciu pełnoletniości (DO 22). Procedury, o którym wyżej, jak podkreśla prawodawca, w żaden sposób nie mogą być odczytywane jako przejaw nieufności czy braku poszanowania dla przekonań niekatolickiego narzeczonego, gdyż ostatecznym celem podejmowania tych środków jest pragnienie, by strony zawarły ważne małżeństwo (DO 42).

Na straży życia wiarą i przekazywania jej potomstwu, prawodawca stawia wymóg w postaci dyspensy od przeszkody różnej religii lub nihil obstat na asystowanie przy zawarciu małżeństwa mieszanego lub małżeństwa z osobą która odstąpiła od wiary katolickiejej. By udzielić zgody/dyspensy w powyższych przypadkach musi istnieć słuszna i rozumna przyczyna oraz spełnione łącznie następujące warunki wymagane przez prawo powszechne: a. obie strony winny być pouczone o celach i istotnych przymiotach małżeńskich; b. strona katolicka deklaruje w formie pisemnej, iż jest gotowa odsunąć od siebie niebezpieczeństwo odejścia od wiary oraz przyrzeknie, że uczyni wszystko by wszystkie dzieci zostały ochrzczone i wychowane w Kościele katolickim ${ }^{29}$; c. druga strona winna być poinformowana o składanych przyrzeczeniach strony katolickiej ${ }^{30}$. Gdyby tą drugą stroną była osoba

\footnotetext{
${ }^{28}$ Konferencja Episkopatu Polski, Instrukcja Episkopatu Polski $w$ sprawie duszpasterstwa małżeństw o różnej przynależności kościelnej (14.09.1987), w: Dokumenty duszpastersko-liturgiczne Episkopatu Polski (1966-1993), red. Cz. Krakowiak, L. Adamowicz, Lublin 1994, s. 251-256.

${ }^{29}$ Gdyby kandydaci do małżeństwa byli w takim wieku, że trudno się spodziewać poczęcia potomstwa, wówczas ta część przyrzeczenia nie będzie brana pod uwagę.

${ }^{30}$ M. GóźDź, Religijne wychowanie potomstwa w małżństwach mieszanych, Katowice 2015, s. 47-52.
} 
która formalnie lub faktycznie odstąpiła od wiary katolickiej winna złożyć w obecności świadków przyrzeczenie na piśmie, że nie będzie przeszkadzała stronie katolickiej w realizacji jej zobowiązań (DO 82). Te tzw. rękojmie są instrumentami pomagającymi duszpasterzom $\mathrm{w}$ wykluczeniu lub przynajmniej w zminimalizowaniu potencjalnego zagrożenia dobra wiary (DO 83). Sporządza się je w trzech egzemplarzach: jeden dołącza się do protokołu przedślubnego, drugi egzemplarz wysyła się do ordynariusza miejsca wraz z prośbą o dyspensę lub pozwolenie, a trzeci - otrzymuje strona katolicka (DO 87).

Warto zwrócić uwagę w kontekście małżeństw mieszanych na zapowiedzi przedślubne, które finalnie również są udokumentowane w postaci aktu potwierdzającego ich wygłoszenie lub opublikowanie. Omawiany dekret ogólny episkopatu reguluje kwestię zapowiedzi w ten sposób, że gdy chodzi o małżeństwo z niekatolikiem ochrzczonym mieszkającym w Polsce, należy się zwrócić do ich własnych pasterzy o wygłoszenie zapowiedzi, o ile tego domagają się ich własne przepisy. Nie publikuje się zaś zapowiedzi w miejscu zamieszkania nieochrzczonych lub tych którzy wystąpili z Kościoła (DO 16) ${ }^{31}$. Po wygłoszeniu zapowiedzi sporządza się adnotacje w formularzu nr 6. Taki kierunek uregulowań wydaje się być bardzo optymalnym, uwzględniającym zarówno unormowania prawne innych Wspólnot kościelnych jak i neutralną obecność tych, którzy nie utożsamiają się z żadną wspólnotą religijną.

\section{Obrzędy zawarcia małżeństwa}

Analizowany dokument Konferencji Episkopatu Polski poza samymi procedurami zmierzającymi do wyeliminowania wszelkich okoliczności przeciwnych zawarciu małżeństwa podejmuje wytyczne związane z celebracją małżeńską. We wskazaniach pojawiają się zarówno oczywiste zasady, jak również te, które budzą wątpliwości zwłaszcza wśród duszpasterzy. Dlatego zestawienie w jednym miejscu

${ }^{31}$ P. Majer, Prace Konferencji Episkopatu Polski nad nową regulacja przygotowania do zawarcia małżeństwa kanonicznego (cz. I), Biuletyn Stowarzyszenia Kanonistów Polskich 32 (2019), s. 149. 
i przypomnienie najnowszych regulacji ogólnokościelnych jest bardzo cennym atutem tegoż dekretu. Pierwsza z przytoczonych zasad brzmi: „małżeństwo mieszane, sprawowane zgodnie $\mathrm{z}$ formą katolicką, odbywa się na ogół poza liturgią eucharystyczną” (DO 88) ${ }^{32}$. Zwrot „na ogół” oznacza możliwość zastosowania wyjątków. Takim wyjątkiem jest okoliczność w której strona katolicka prosi ordynariusza miejsca o zezwolenie na celebrację ślubną podczas sprawowania Eucharystii. Za tą prośbą muszą przemawiać wystarczające przesłanki skłaniające ordynariusza miejsca do udzielenia pozytywnej odpowiedzi. Gdy mamy do czynienia z małżeństwem katolika z prawosławnym, to połączenie sakramentu małżeństwa $z$ Eucharystią nie wymaga zgody władzy wykonawczej ${ }^{33}$. Jednoznacznie w innym tonie wybrzmiewa dyspozycja dotycząca małżeństwa katolika z katechumenem lub niechrześcijaninem. „W tym przypadku nie dopuszcza się zawierania małżeństwa podczas Mszy św., a ordynariusz miejsca nie jest uprawniony do wyrażenia na to zgody" (DO 88). Księga zawierająca celebracje małżeńskie zawiera obrzęd uwzględniający powyższą sytuację ${ }^{34}$.

Nowością dokumentu, w omawianej problematyce, jest możliwość zaproszenia przez kapłana katolickiego, „szafarza z Kościoła lub Wspólnoty eklezjalnej strony niekatolickiej do udziału w celebrowaniu małżeństwa” (DO 89). Udział zaproszonego szafarza sprowadza się do odczytania Pisma św. i skierowania do nowożeńców zachęty oraz wypowiedzenia modlitwy błogosławieństwa. Nie jest zaś możliwym, by zaproszony gość wchodził w rolę świadka kwalifikowanego, albo podejmował tę rolę obok świadka urzędowego (kan. $1127 \S 3$ KPK). Taki klucz jedności eklezjalnej, niesie za sobą probierz jedności w małżeńskiej różnorodności wyznaniowej czy religijnej. Dlatego warto ten postulat episkopatu wdrażać w życie.

\footnotetext{
${ }^{32}$ Konferencja Episkopatu Polski, Obrzędy sakramentu małzeństwa dostosowane do zwyczajów diecezji polskich, Katowice 1996, nr 122-150.

${ }^{33}$ Papieska Rada ds. Rodziny, Przygotowanie (13.05.1996), nr 64.

${ }^{34}$ Konferencja Episkopatu Polski, Obrzędy sakramentu małżństwa, dz. cyt., nr 81 i nast.
} 
Dekret ogólny przewiduje, że mogą pojawić się sytuacje, w których strona katolicka prosi o dyspensę od zachowania formy kanonicznej (kan. $1127 \$ 2$ KPK). Przyczyny mogą być następujące: „zachowanie harmonii rodzinnej, uzyskanie zgody rodziców na małżeństwo, uznanie szczególnego zaangażowania religijnego strony niekatolickiej bądź jej więź pokrewieństwa z szafarzem innego Kościoła lub Wspólnoty eklezjalnej” (DO 90). Po rozważeniu skierowanej prośby, ordynariusz miejsca strony katolickiej może, po zasięgnięciu opinii ordynariusza miejsca, w którym małżeństwo będzie zawierane, udzielić rzeczonej dyspensy. Zanim to jednak nastąpi, proboszcz strony katolickiej przeprowadza pełne badanie kanoniczne narzeczonych w zwyczajny sposób (DO 91) ${ }^{35}$. Ważnym pozostaje uwarunkowanie polegające na tym, że małżeństwo będzie zawarte z zachowaniem jakiejś formy publicznej (DO 92) ${ }^{36}$. Po fakcie zaślubin strona katolicka zobowiązana jest poinformować duchownego, który przeprowadził kanoniczne badanie narzeczonych, o zawartym małżeństwie. Podstawą tej informacji jest odpowiedni dokument potwierdzający zawarcie małżeństwa. Celem tego przepisu jest dokonanie wpisu do księgi małżeństw i chrztu strony katolickiej oraz sporządzenie aktu małżeństwa, który podpisuje małżonek katolicki i duchowny (DO 94).

Trwając nadal w obszarze formy kanonicznej, należy uwzględnić udział świadków w obrzędzie zaślubin. Z zasady świadkami zawarcia małżeństwa winni być katolicy, chodzi bowiem o ich jak najpełniejszy udział w obrzędach liturgicznych łącznie z możliwością udziału w Komunii eucharystycznej ${ }^{37}$. Gdy jednak jest zawierane małżeństwo mieszane, wówczas jednym ze świadków może być ochrzczony niekatolik (DO 110) ${ }^{38}$.

\footnotetext{
${ }^{35}$ Mając na uwadze zwyczajny sposób, należy wziąć pod uwagę sporządzenie protokołu kanoniczno-duszpasterskiego, stwierdzić stan wolny stron oraz integralność konsensu. W razie potrzeby należy uzyskać potrzebne zezwolenia i dyspensy, w tym zezwolenie na zawarcie małżeństwa mieszanego.

${ }^{36}$ Omawianą sytuację przewidział Kodeks z 1983 r. w kan. $1127 \$ 2$.

${ }^{37}$ Papieska Rada do spraw Rodziny, Przygotowanie (13.05.1996), nr 66-68.

${ }^{38}$ Konferencja Episkopatu Polski, Instrukcja dla duszpasterzy (22.10.1998), nr 18c: „Zaświadczenie o zawarciu małżeństwa” powinno być podpisane przez
} 
Nie sposób pominąć jeszcze jednej szczegółowej kwestii uregulowanej dekretem episkopatu. Chodzi o małżeństwo zawarte przez katolika z osobą należącą do wschodniego Kościoła akatolickiego wobec tamtejszego świętego szafarza (kan. $1127 \$ 1 \mathrm{KPK}$ ) bez dyspensy od formy kanonicznej. Zgodnie z prawem takie małżeństwo jest ważne choć zawarte nielegalnie. Dlatego, stronę katolicką zanim zostanie dopuszczona do Komunii eucharystycznej, należy zweryfikować, czy nie zostały naruszone zasady prawa Bożego oraz czy strona katolicka spełniła wszystkie warunki do ważnego zawarcia małżeństwa. W tym celu małżonkowie (de facto już po zawartym małżeństwie w cerkwi) udają się do duchownego rzymskokatolickiego miejsca zamieszkania strony katolickiej, w celu sporządzenia protokołu rozmów kanoniczno-duszpasterskich. Należy przedłożyć świadectwo ślubu zawartego w cerkwi oraz świadectwo chrztu, ponadto strona katolicka winna złożyć przyrzeczenie i oświadczenie odnoszące się do małżeństw mieszanych. Duchowny przekazuje całą dokumentację do kurii diecezjalnej aby uzyskać od ordynariusza miejsca uprawomocnienie tego małżeństwa na forum Kościoła katolickiego. Po pozytywnej weryfikacji zostaje wydana deklaracja przez ordynariusza miejsca. Na jej bazie duchowny sporządza akt małżeństwa w księdze parafialnej i ma spowodować odnotowanie zawartego w cerkwi małżeństwa w księdze chrztów strony katolickiej (DO 117).

\section{Zakończenie}

Episkopat Polski publikując Dekret ogólny o przeprowadzeniu rozmów kanoniczno duszpasterskich z narzeczonymi przed zawarciem małżeństwa kanonicznego spełniła oczekiwania wspólnot parafialnych, dając jasno określone wytyczne w tak istotnej materii dla życia społeczności kościelnej. Stało się tak dlatego, że wdrożony akt prawny nie jest oderwany od aktualnego kontekstu społecznego w Polsce. Zmieniająca się mentalność społeczeństwa i ewaluujące uwarunkowania społeczne przyczyniają się do tego, że etap przygotowania

duchownego asystującego przy zawarciu małżeństwa, jak „również przez małżonków i dwóch pełnoletnich świadków, czyli mających ukończony 18. rok życia”. 
do małżeństwa wymagał nowego spojrzenia, a w konsekwencji weryfikacji poszczególnych unormowań. W Dekrecie uwzględniono zarówno polaryzującą się wiarę młodego człowieka jak również nowe konstelacje par przygotowujących się do wspólnej życiowej drogi. A ponadto, dokument episkopatu naznaczony jest ogromną wrażliwością na indywidualność narzeczonych. Wspomniana indywidualność potencjalnych rozmówców kancelaryjnych prowadzi często do ich utożsamienia się, z nurtem indywidualizmu, ten z kolei stawia jednostkę-osobę na piedestale wartości, uznając ją za najwyższe dobro. I tak oto duża część społeczności bardzo pielęgnuje zarysowany model myślenia. Stąd sugestia Konferencji Episkopatu do wszystkich duszpasterzy posługujących w kancelarii parafialnej, by cechowała ich empatia, wrażliwość i delikatność (DO 6). Ale czy taka postawa nie stwarza narzeczonym przestrzeni roszczeniowej? Odpowiedź dadzą konkretne doświadczenia. Natomiast omawiany dokument nacechowany jest ogromną elastycznością. Taki sposób podejścia do rozwiązywania potencjalnych trudności wskazuje na służebny charakter Kościoła i podjęcie wynikających z tego konsekwencje. Stąd płynąca zachęta ze strony episkopatu ku duszpasterzom, by z powagą i odpowiedzialnością poruszali zagadnienia dotykające trudności z jakimi mogą się zderzyć w małżeństwie na tle różnic wyznaniowych czy religijnych.

Warto raz jeszcze podkreślić, że dokument koncentruje swą uwagę na tzw. egzaminie przedmałżeńskim, zaś przygotowanie się kandydatów do małżeństwa wymaga dużo czasu, udziału wielu osób oraz osobistego wielkiego zaangażowania samych zainteresowanych. Nie można w tym zaangażowaniu pominąć troski o rozwój życia duchowego. Wówczas dopiero można mieć przekonanie, że zaowocuje ono w dobrze przeżytym małżeństwie, a w konsekwencji, w satysfakcji z uszczęśliwiającego małżeństwa. 


\section{Mixed marriage preparation in the light of a General Decree issued by Polish Episcopate on October $8^{\text {th }} 2019$}

After more than 30 years of applying the Instruction for the marriage preparation, it has been replaced by new General Decree of the Episcopate of Poland which has become effective on June $1^{\text {st }} 2020$. The material extent of the new document was restricted to conducting prenuptial investigation. Dynamically changing social and religious patterning enforce the need of new regulations of direct marriage preparation. It's aimed at discerning in legal situation i.e. in exclusion the circumstances opposing to enter in marriage or to sort this by dispensation or permission by competent authority.

The present study is focused on mixed marriages, in the light of c. 1086 $\$ 1$ and c. 1124 CCL. It happens more and more often: entering marriages of various confessions and religions. This diversity carries various beliefs, traditions and experiences. It is necessary on the part of a minister to act with discretion, propriety and consideration; on the other side, with a care and diligence to regard the law of the Church on marriage to lead the betrothed to fruitful in God's grace marriage on the ecclesiastical ground. To achieve this goal it is advisable to begin the investigation with a prayer and an oath of the parties regarding their truthful and correct answers. As a result of properly conducted investigation, it is time to make decision regarding not only the proper rite of a marriage (with or without a mass) but also regarding the participation of non - catholic minister, with his role precisely described.

The document, long-awaited, should prove itself and suit the priests conducting prenuptial investigation. It is marked by more precise accuracy in resolving the nuances which may appear in the course of this stage of marriage preparation.

SŁOWA KLUCZOWE: dekret ogólny episkopatu; egzamin przedślubny; przygotowanie bezpośrednie; małżeństwa mieszane

KEYWORDs: general episcopal decree; premarital examination; immediate preparation; mixed marriages

\section{Nota o Autorze}

Ks. DR HAB. KAZIMIERz DullaK, PROF. UCZELni - pracownik naukowo-dydaktyczny Wydziału Teologicznego Uniwersytetu Szczecińskiego, kierownik Katedry Prawa Kanonicznego. 